\title{
Vitamin D and Thyroid Diseases
}

\author{
K. VONDRA ${ }^{1}$, L. STÁRKA ${ }^{1}$, R. HAMPL ${ }^{1}$ \\ ${ }^{1}$ Institute of Endocrinology, Prague, Czech Republic
}

Received May 26, 2015

Accepted June 9, 2015

\begin{abstract}
Summary
In this review we summarize recent opinions on the possible role of vitamin $D$ in the risk of thyroid diseases development. It may be concluded from the available data that vitamin $\mathrm{D}$ deficiency, particularly levels below $12.5 \mathrm{ng} / \mathrm{ml}$ should be considered as an additional, but important risk factor for development of thyroid autoimmunity, both chronic autoimmune thyroiditis and Graves' disease. A higher risk of Graves' disease development is also associated with several polymorphisms in the gene encoding for vitamin $\mathrm{D}$ binding protein and for the specific receptor of active form of vitamin $D-1,25-(O H)_{2} D_{3}$ in the respective target cells. Important for development of thyroid cancer appeared polymorphisms of genes encoding for vitamin $D$ receptors and of genes encoding for the participating hydroxylating enzymes in thyroid tissue, leading to a diminished local $1,25-(\mathrm{OH})_{2} \mathrm{D}_{3}$ formation capacity with following alteration of antiproliferatory, antiapoptotic and prodifferentiating efficacy of the latter. Whether supplementation with high doses of vitamin D or its analogues possesses preventive or therapeutic effect is an object of intensive studies.
\end{abstract}

\section{Key words}

Vitamin D • Thyroid disease • Autoimmunity • Thyroid cancer

\section{Corresponding author}

K. Vondra, Institute of Endocrinology, Národní 8, 11600 Prague 1, Czech Republic. E-mail: kvondra@endo.cz

\section{Introduction}

Nowadays one may encounter an increasing number of reports on the relationships between vitamin D deficiency and the risk of a number of systemic and organ diseases outside the bone system. Emphasized is especially its role in autoimmune (Agmon-Levin et al.
2013) and oncological diseases (De Mille 2014) and diabetes mellitus (Badenhoop et al. 2012), the importance of physiological saturation with vitamin D for normal fetal development during pregnancy and further postnatal life (Pérez López et al. 2015), the effects of vitamin D on the aging including mortality (Samefors et al. 2014) and its association with mental health (Kerr et al. 2015). In this review we tried to summarize and discuss recent opinions on the possible role of vitamin D in the risk of thyroid diseases development, as the most frequent endocrinopathies.

\section{Physiology and pathophysiology of vitamin D saturation}

Only $25(\mathrm{OH}) \mathrm{D}_{3}$ (calcidiol) is being currently used in the world for clinical evaluation of the vitamin D saturation. It is considered as the real indicator of the total vitamin $\mathrm{D}$ stores. The $25(\mathrm{OH}) \mathrm{D}_{3}$ levels are relatively stable for several days or weeks and oscillate in dependence on sun radiation rather than on vitamin D precursors intake from food. About $99 \%$ of circulating $25(\mathrm{OH}) \mathrm{D}_{3}$ is present in a bound form with vitamin $\mathrm{D}$ binding proteins, so that around $1 \%$ of free vitamin $\mathrm{D}$ is available.

So far there is not unequivocal consensus in evaluation of physiological $25(\mathrm{OH}) \mathrm{D}_{3}$ levels. Though the value $20 \mathrm{ng} / \mathrm{ml}$ is considered sufficient as concerns its skeletal effects, the values up to $30 \mathrm{ng} / \mathrm{ml}$ are still associated with manifestation of vitamin D deficiency in organs outside the bone system according to epidemiological data. The upper borderline of $25(\mathrm{OH}) \mathrm{D}_{3}$ in blood from the point of view of a safe dose has not yet been established and is a subject of discussion. 


\section{Hormonal mechanism of vitamin D effects}

Most of human cells is capable to exprime 1-alpha-hydroxylase (encoded by the CYP27B1) by which $25(\mathrm{OH}) \mathrm{D}_{3}$, after its entering the cells, is further hydroxylated giving rise an active vitamin $\mathrm{D}$ form, 1,25- $(\mathrm{OH})_{2} \mathrm{D}_{3}$ (calcitriol). Recent evidence, however supports the idea that circulating $1,25-(\mathrm{OH})_{2} \mathrm{D}_{3}$ levels in blood probably reflect only its formation in cells of proximal tubule of the kidney. The biological half-time of $1,25-(\mathrm{OH})_{2} \mathrm{D}_{3}$ is only $4-6 \mathrm{~h}$. Its renal formation is regulated by circulating calcium and phosphate, parathormone and especially by the final product, calcitriol itself, and it is utilized preferably for bone metabolism. Other cells than those from renal tissues can express vitamin $\mathrm{D}$ receptor (VDR) as well as 1-alpha-hydroxylase, which allows the tissue specific up regulation of $1,25-(\mathrm{OH})_{2} \mathrm{D}_{3}$ formation according to their own needs.

Such a paracrine/autocrine regulation of tissue calcitriol formation, independent on parathormone, proceeds via different regulatory mechanisms than govern its renal formation. It may explain pleiotrophic effects of vitamin D on human organism. A necessary precondition for functioning of this non-skeletal component of vitamin D metabolism is a sufficient supply of its precursor, namely $25(\mathrm{OH}) \mathrm{D}_{3}$ in the body and it may explain the negative impact of vitamin D deficiency for the whole organism. Mutation of genes encoding for tissue hydroxylases contributes significantly to cancer development. Biologically active $1,25-(\mathrm{OH})_{2} \mathrm{D}_{3}$ bound to special receptors penetrates to the cell nucleus. Here it gives rise to a final complex with retinoic acid, which interacts with vitamin D responsible elements in the promotor region of the regulated gene. The final effect is an activation or suppression of as many as 200-500 genes, representing about $3-5 \%$ of the human genome. The active form of vitamin $\mathrm{D}$ functions here as classical hormone acting via nuclear receptors of the thyroid/gluco- or mineralocorticoid and other family.

With respect to the topics of this review, the most important are the genes, ensuring physiological function of the immune system, including innate as well as acquired immunity, and proteins responsible for cell growth and differentiation, antiproliferatory and/or antiphlogistic effects.

\section{Chronic autoimmune thyroiditis}

Chronic autoimmune thyroiditis is the most frequent endocrinopathy. Using a competitive immunoassay procedure, the reported prevalence of detectable thyroid antibodies, primarily TPOAb levels, amounted $10-12 \%$ of the healthy population. A hypoechoic ultrasound pattern or an irregular echo pattern may precede TPOAb positivity in autoimmune thyroid disease and TPOAb may not be detected in about $20 \%$ of individuals with ultrasound evidence of thyroid autoimmunity (Vanderpump 2011). In high risk groups such as older women, female with type 1 diabetes and in subjects with a positive family history, the prevalence reaches as much as $20-40 \%$.

The available data from studies on occurrence of vitamin D deficiency in relation to thyroid diseases mostly prove the association of vitamin D deficiency with higher incidence of autoimmune thyroiditis (Bizzaro and Shoenfeld 2015). More severe deficiency is often accompanied by thyroid hypofunction (Kivity et al. 2011, Tamer et al. 2011, Bozkurt et al. 2013). The levels of $25(\mathrm{OH}) \mathrm{D}_{3}$ seem to be an independent factor influencing the presence of TPOAb positivity (Shin et al. 2014). The differences in vitamin D levels between children with autoimmune thyroiditis and healthy children are more pronounced than in adult population (Camurdan et al. 2012). Our own experience from examination of adult patients treated in the Institute of Endocrinology for autoimmune thyroiditis fully agrees with the data in the literature. The average initial value of $25(\mathrm{OH}) \mathrm{D}_{3}$ in patients with newly onset of autoimmune thyroiditis was found in the range of a deep deficit $\left(25(\mathrm{OH}) \mathrm{D}_{3}-\right.$ $11.4(4.4-20.2 \mathrm{ng} / \mathrm{ml})$, while in as many as $84 \%$ patients the levels were lower than $10 \mathrm{ng} / \mathrm{ml}$. In the subgroup patients with vitamin D levels below $10 \mathrm{ng} / \mathrm{ml}$ a hypofunction of the thyroid was found in $60 \%$ at the time of diagnosis, while in patients with normal values of $25(\mathrm{OH}) \mathrm{D}_{3}$ it occurred only in $20 \%$.

From the pathophysiological point of view chronic autoimmune thyroiditis and its forms represent organ-specific autoimmune disease. The key role in the development of autoimmune process play genetically dependent aberrant expression of HLA DR and other antigens on the thyreocyte surface, causing that these cells become prone to an autoimmune attack.

The unique immunomodulatory effect of $1,25-(\mathrm{OH})_{2} \mathrm{D}_{3}$ consists in influencing not only T-lymphocyte function, but also antigen presenting cells. In the experimental animals (mice) 1,25-(OH) ${ }_{2} \mathrm{D}_{3}$ stimulated fagocytosis and, on the other hand, suppressed the activity of macrophages and dendritic cells, resulting 
in an decreased presentation of autoantigens. An active form of vitamin $\mathrm{D}, 1,25-(\mathrm{OH})_{2} \mathrm{D}_{3}$ significantly inhibited secretion of the key Th1 proinflammatory cytokines by antigen presenting cells resulting in inhibition of cytodestructive (cytotoxic) Th1 lymphocytes, and enhances Th2 cytokine (IL-4) production (Sterzl 2012).

An assumption that $1,25-(\mathrm{OH})_{2} \mathrm{D}_{3}$ can influence the course of autoimmune inflammation through this mechanism was confirmed experimentally. The experimental studies have proven direct protective effect of $1,25-(\mathrm{OH})_{2} \mathrm{D}_{3}$ in combination with suppression of an autoimmune inflammation, along with abovementioned influencing of T-lymphocytes and an impact on antigen presenting cells, especially dendritic cells.

Eliciting of such an immunomodulatory effect by using active $1,25-(\mathrm{OH})_{2} \mathrm{D}_{3}$ even in man supposes application of high (pharmacological) doses with undesired effects on bone remodelation and hypercalcemic states. Under development are therefore synthetic analogues of $1,25-(\mathrm{OH})_{2} \mathrm{D}_{3}$ with retained immunomodulatory activity, but with a reduced effect on calcium- and bone metabolism. Some of them appeared to prevent progression of autoimmune inflammation in experiment with NOD mice. Calcipotriol is recently used in human medicine in the treatment of psoriasis, and the same substance and its analogs are tested as potent antiproliferative agents on leukemia, breast and colon cancer (more details see in Wierzbicka et al. 2014).

The presence of $1,25-(\mathrm{OH})_{2} \mathrm{D}_{3}$ or its analogues in an in vitro system results in formation of dendritic cells with specific features: let us mention a decrease of IL 12, reduced CD80/CD86 expression and generally MHC II expression and, the most important, decreased stimulation of effector- and specific regulatory T-cells (Ferreira et al. 2014). These findings are recently examined under clinical condition (Nikolic and Roep 2013) consisting in an autotransfer of dendritic cells formed by peripheral monocytes in patients which were exposed ex vivo to high concentrations of $1,25-(\mathrm{OH})_{2} \mathrm{D}_{3}$ or its analogues. It appeared that immediately after the retransfer back to the patient these dendritic cells were capable to shift the immune system from attack towards a tolerance to affected cells. In spite still ambiguous and inconclusive results of the studies about association between a functional polymorphism in the vitamin D receptor (VDR) and autoimmune thyroiditis risk, it is worth to mention meta-analysis of relevant literature made recently by Feng et al. (2013). The authors found that the cumulative effect of VDR gene Bsml or Taql polymorphism in Europeans is significantly associated with autoimmune thyroiditis.

For details about the role vitamin $\mathrm{D}$ in the etiopathogenesis of autoimmune thyroiditis see Kivity et al. (2011), Effraimidis and Wiersinga (2014), Mazokopakis and Kotsiris (2014), Muscogiuri et al. (2014), Antonelli et al. (2015).

It may be concluded from the available data of both experimental and clinical studies that the values of vitamin D below $12.5 \mathrm{ng} / \mathrm{ml}$ should be considered an additional, but important risk factor for development of chronic autoimmune thyroiditis. Whether supplementation with high doses of vitamin D or its analogues possesses preventive or therapeutic effect is an object of intensive studies (Muscogiuri et al. 2015).

\section{Graves' disease}

Graves' disease (GD) is much more severe form of the thyroid gland autoimmunity than chronic autoimmune thyroiditis, mainly for negative impacts of high thyroid hormone levels on vital functions, which may be life threatening especially in aged people. Its occurrence is much lower in comparison to chronic autoimmune thyroiditis in normal population it is estimated 4 per 10000 for women and 1 per 10000 in men, but the age-specific incidence varies considerably (Vanderpump 2011).

Most of the available data point to a higher prevalence of $25(\mathrm{OH}) \mathrm{D}_{3}$ deficiency also at this form of thyroid autoimmunity. More pronounced decreased levels of $25(\mathrm{OH}) \mathrm{D}_{3}$ have been found mainly early after establishing of GD diagnosis (Yasuda et al. 2012). Higher deficit predicted later disease remission in some studies. Some authors who followed long-term development of the disease found significantly lower $25(\mathrm{OH}) \mathrm{D}_{3}$ values in diseases in an active phase of GD in comparison to patients in a full remission (Yasuda et al. 2013). Inverse correlations were also described between $25(\mathrm{OH}) \mathrm{D}_{3}$ levels and thyroid gland volume in GD patients (Yasuda et al. 2012).

Association of high thyroid hormone levels with low $1,25-(\mathrm{OH})_{2} \mathrm{D}_{3}$ level rose the question about the molecular mechanism behind it. Recent experiment with $\mathrm{T}_{3}$-induced hyperthyroid mice revealed not only marked decrease of plasma $1,25-(\mathrm{OH})_{2} \mathrm{D}_{3}$, but also reduced renal mRNA expression of $C Y P 27 B 1$ gene, the gene encoding for vitamin D 1-alpha-hydroxylase. This effect was independent on parathormone. Further promotor analysis 
revealed that $\mathrm{T}_{3}$ decreased the transcriptional activity of the CYP27B1 gene through thyroid hormone receptors of both types (TR alpha and beta 1) and binding of thyroid hormone-receptor complex to DNA thyroid hormone responsive elements, in concert with retinoid $\mathrm{X}$ receptor. Of interest may be another finding of the authors that the negative thyroid hormone responsive elements overlap with some so called sterol regulatory elements, responsible for an opposite effect - a positive regulation of CYP27B1 gene transcription (Kozai et al. 2013).

A higher risk of GD development is also associated with several polymorphisms in the gene encoding for VDR and for the specific receptor of active form of vitamin $\mathrm{D}-1,25(\mathrm{OH})_{2} \mathrm{D}_{3}$ - in the respective target cells. Such polymorphisms were revealed in some populations with a higher risk of GD development, as for instance in Germany, Poland, or Egypt but not in Serbia (Ramos-Lopez et al. 2005, Kurylowicz et al. 2006, Abd El Gawad et al. 2012). Due to remarkable variability in individual risk polymorphisms, including their association with GD among populations, the clinical relevance of these findings is not significant. In conclusion, existing data support the idea about the role of vitamin D in GD development, but further epidemiological and especially intervention studies are needed.

\section{Polymorphisms of genes encoding for vitamin D receptors and for vitamin D hydroxylating enzymes - relation to thyroid cancer}

Important for development of thyroid cancer appeared polymorphisms of genes encoding for VDR, leading to a diminished local efficacy of $1,25(\mathrm{OH})_{2} \mathrm{D}_{3}$, with respect to remarkable antiproliferatory, antiapoptotic and prodifferentiating activity of the latter (Clinckspoor et al. 2013). Such polymorphisms were repeatedly found not only in thyroid cancers, the most common endocrine malignancy, but also have been reported to increase the risk of other tumors such as in breast, prostate, colon and others (Penna-Martinez et al. 2012). Similarly alterations of $1,25-(\mathrm{OH})_{2} \mathrm{D}_{3}$ formation due to polymorphisms of genes encoding for the participating hydroxylating enzymes, resulting in its low levels were described in papillary, follicular as well as anaplastic thyroid cancers. The levels of $1,25-(\mathrm{OH})_{2} \mathrm{D}_{3}$ even correlated with cancer stages (I-IV) (Penna-Martinez et al. 2009, Stepien et al. 2010). Of great importance, emphasizing the relevance of the final hydroxylating step in the biosynthesis of the biologically active hormone, is the simultaneous absence of any association of thyroid cancer diagnosis or disease stage with $25(\mathrm{OH}) \mathrm{D}_{3}$ levels, reported in most of these studies. In other words, thyroid cancer development does not depend probably on the total saturation with vitamin D (Jonklaas et al. 2013).

\section{Conclusions}

Based on our experience and data from the literature it may be expected that significant vitamin D deficiency would occur in the most of the subjects suffering from various forms of thyroid autoimmunity. The question arises, how to react to this situation. Whether to recommend sunning, bearing however many risks (skin aging, provoking of inflammation or even cancerogenic effect) and/or food supplements containing vitamin D precursors, or pharmacological substitution. Vitamin D supplementation should be offered to the deficient patients, the current opinion considers as optimal and at the same time safe a serum blood level of $25(\mathrm{OH}) \mathrm{D}_{3}$ within the range $30-40 \mathrm{ng} / \mathrm{ml}(75-100 \mathrm{nmol} / \mathrm{l})$. In the most valid studies such levels are believed to possess a number of beneficial effects. Whether supplementation with high doses of vitamin D or its analogues has preventive or therapeutic effect on thyroid autoimmunity is a subject of intensive studies.

\section{Conflict of Interest}

There is no conflict of interest.

\section{Acknowledgements}

Supported by MH CZ - DRO (Institute of Endocrinology - EÚ, 00023761).

\section{References}

ABD EL GAWAD SS, ABDUL SAMEE ER, METWALI AA, ABD EL GAWAD MS: Vitamin D receptor gene polymorphism and its association with 1,25-dihydroxyvitamin D in patients with Graves disease in an Egyptian population: a pilot study. Endocr Pract 18: 132-139, 2012.

AGMON-LEVIN N, THEODOR E, SEGAL RM, SCHOENFELD Y: Vitamin D in systemic and organ- specific autoimmune diseases. Clin Rev Allergy Immunol 45: 256-266, 2013. 
ANTONELLI A, FERRARI SM, CORRADO A, DI DOMENICANTONIO A, FALLAHI P: Autoimmune thyroid disorders. Autoimmun Rev 14: 174-180, 2015.

BADENHOOP K, KAHLES H, PENNA-MARTINEZ M: Vitamin D, immune tolerance, and prevention of type 1 diabetes. Curr Diab Rep 12: 635-642, 2012.

BIZZARO G, SHOENFELD Y: Vitamin D and autoimmune thyroid diseases: facts and unresolved questions. Immunol Res 61: 46-52, 2015.

BOZKURT NC, KARBEK B, UCAN B, SAHIN M, CAKAL E, OZBEK M, DELIBASI T: The association between severity of vitamin D deficiency and Hashimoto's thyroiditis. Endocr Pract 19: 479-484, 2013.

CAMURDAN OM, DÖĞER E, BIDECI A, CELIK N, CINAZ P: Vitamin D status in children with Hashimoto thyroiditis. J Pediatr Endocrinol Metab 25: 467-470, 2012.

CLINCKSPOOR I, VERLINDEN L, MATHIEU C, BOUILLON R, VERSTUYF A, DECALLONNE B: Vitamin D in thyroid tumorigenesis and development. Prog Histochem Cytochem 48: 65-98, 2013.

DeMILLE DM, PISCITELLI M, OCKER A, VUONG C, HARTNER L, LYNCH MP: Vitamin D deficiency in the oncology setting. J Community Support Oncol 12: 13-19, 2014.

EFFRAIMIDIS G, WIERSINGA WM: Mechanisms in endocrinology: autoimmune thyroid disease: old and new players. Eur J Endocrinol 170: R241-R252, 2014.

FENG M, LI H, CHEN SF, LI WF, ZHANG FB: Polymorphisms in the vitamin D receptor gene and risk of autoimmune thyroid diseases: a meta-analysis. Endocrine 43: 318-326, 2013.

FERREIRA GB, GYSEMANS CA, DEMENGEOT J, DA CUNHA JP, VANHERWEGEN AS, OVERBERGH L, VAN BELLE TL, PAUWELS F, VERSTUYF A, KORF H, MATHIEU C: 1,25-Dihydroxyvitamin D3 promotes tolerogenic dendritic cells with functional migratory properties in NOD mice. $J$ Immunol 192: 4210-4220, 2014.

JONKLAAS J, DANIELSEN M, WANG H: A pilot study of serum selenium, vitamin D, and thyrotropin concentrations in patients with thyroid cancor. Thyroid 23: 1079-1086, 2013.

KERR DC, ZAVA DT, PIPER WT, SATURN SR, FREI B, GOMBART AF: Associations between vitamin D levels and depressive symptoms in healthy young adult women. Psychiatry Res 227: 46-51, 2015.

KIVITY S, AGMON-LEVIN N, ZISAPPL M, SHAPIRA Y, NAGY EV, DANKÓ K, SZEKANECZ Z, LANGEVITZ P, SHOENFELD Y: Vitamin D and autoimmune thyroid diseases. Cell Mol Immunol 8: 243-247, 2011.

KOZAI M, YAMAMOTO H, ISHIGURO M, HARADA N, MASUDA M, KAGAWA T, TAKEI Y, OTANI A, NAKAHASHI O, IKEDA S, TAKETANI Y, TAKEYAMA K, KATO S, TAKEDA E: Thyroid hormones

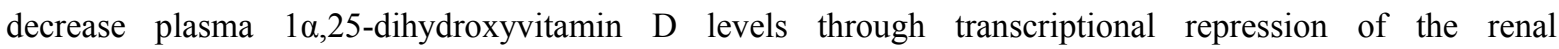
25-hydroxyvitamin D3 1 $\alpha$-hydroxylase gene (CYP27B1). Endocrinology 154: 609-622, 2013.

KURYLOWICZ A, RAMOS-LOPEZ E, BEDNARCZUK T, BADENHOOP K: Vitamin D-binding protein (DBP) gene polymorphism is associated with Graves' disease and the vitamin D status in a Polish population study. Exp Clin Endocrinol 114: 329-335, 2006.

MAZOKOPAKIS EE, KOTSIRIS DA: Hashimoto's autoimmune thyroiditis and vitamin D deficiency. Current aspects. Hell J Nucl Med 17: 37-40, 2014.

MUSCOGIURI G, MITRI J, MATHIEU C, BADENHOOP K, TAMER G, ORIO F, MEZZA T, VIETH R, COLAO A, PITTAS A: Mechanisms in endocrinology: vitamin D as a potential contributor in endocrine health and disease. Eur J Endocrinol 171: R101-R110, 2014.

MUSCOGIURI G, TIRABASSI G, BIZZARO G, ORIO F, PASCHOU SA, VRYONIDOU A, BALERCIA G, SHOENFELD Y, COLAO A: Vitamin D and thyroid disease: to D or not to D? Eur J Clin Nutr 69: 291-296, 2015.

NIKOLIC T, ROEP BO: Regulatory multitasking of tolerogenic dendritic cells - lessons taken from vitamin D3-treated tolerogenic dendritic cells. Front Immunol 14: 113, 2013.

PENNA-MARTINEZ M, RAMOS-LOPEZ E, STERN J, HINSCH N, HANSMANN ML, SELKINSKI I, GRÜNWALD F, VORLÄNDER C, WAHL RA, BECHSTEIN WO, ZEUZEM S, HOLZER K, BADENHOOP K: Vitamin D receptor polymorphisms in differentiated thyroid carcinoma. Thyroid 19: 623-628, 2009. 
PENNA-MARTINEZ M, RAMOS-LOPEZ E, STERN J, KAHLES H, HINSCH N, HANSMANN ML, SELKINSKI I, GRÜNWALD F, VORLÄNDER C, BECHSTEIN WO, ZEUZEM S, HOLZER K, BADENHOOP K: Impaired vitamin D activation and association with CYP24A1 haplotypes in differentiated thyroid carcinoma. Thyroid 22: 709-716, 2012.

PÉREZ-LÓPEZ FR, PASUPULETI V, MEZONES-HOLGUIN E, BENITES-ZAPATA VA, THOTA P, DESHPANDE A, HERNANDEZ AV: Effect of vitamin D supplementation during pregnancy on maternal and neonatal outcomes: a systematic review and meta-analysis of randomized controlled trials. Fertil Steril 103: 1278-1288, 2015.

RAMOS-LOPEZ E, KURYLOWICZ A, BEDNARCZUK T, PAUNKOVIC J, SEIDL C, BADENHOOP K: Vitamin D receptor polymorphisms are associated with Graves' disease in German and Polish but not in Serbian patients. Thyroid 15: 1125-1130, 2005.

SAMEFORS M, ÖSTGREN CJ, MÖLSTAD S, LANNERING C, MIDLÖV P, TENGBLAD A: Vitamin D deficiency in elderly people in Swedish nursing homes is associated with increased mortality. Eur J Endocrinol 170: 667-675, 2014.

SHIN DY, KIM KJ, KIM D, HWANG S, LEE EJ: Low serum vitamin D is associated with anti-thyroid peroxidase in autoimmune thyroiditis. Yonsei Med J 55: 476-478, 2014.

STEPIEN T, KRUPINSKI R, SOPINSKI J, KUZDAK K, KOMOROWSKI J, LAWNICKA H, STEPIEN H: Decreased 1-25 dihydroxyvitamin D3 concentration in peripheral blood serum of patients with thyroid cancer. Arch Med Res 41: 190-194, 2010.

STERZL I: D vitamin and imunity (in Czech). Vnitr Lek 58: 405-410, 2012.

TAMER G, ARIK S, TAMER I, COKSERT D: Relative vitamin D insufficiency in Hashimoto's thyroiditis. Thyroid 21: 891-896, 2011.

VANDERPUMP MP: The epidemiology of thyroid disease. Br Med Bull 99: 39-51, 2011.

WIERZBICKA J, PIOTROWSKA A, ŻMIJEWSKI MA: The renaissance of vitamin D. Acta Biochim Pol 61: 679-686, 2014.

YASUDA T, OKAMOTO Y, HAMADA N, MIYASHITA K, TAKAHARA M, SAKAMOTO F, MIYATSUKA T, KITAMURA T, KATAKAMI N, KAWAMORI D, OTSUKI M, MATSUOKA TA, KANETO H, SHIMOMURA I: Serum vitamin D levels are decreased and associated with thyroid volume in female patients with newly onset Graves' disease. Endocrine 42: 739-741, 2012.

YASUDA T, OKAMOTO Y, HAMADA N, MIYASHITA K, TAKAHARA M, SAKAMOTO F, MIYATSUKA T, KITAMURA T, KATAKAMI N, KAWAMORI D, OTSUKI M, MATSUOKA TA, KANETO H, SHIMOMURA I: Serum vitamin D levels are decreased in patients without remission of Graves' disease. Endocrine 43: 230-232, 2013. 